\title{
The Study of the Effect of Corporate Governance on Profit Management of the Accepted Companies in Tehran Stock Exchange
}

\author{
Masoud Taherinia ${ }^{1} \&$ Ehsan Zeynivand ${ }^{2}$ \\ ${ }^{1}$ Assistant professor, Department of management, Lorestan University, Khorramabad, Iran \\ ${ }^{2}$ Master of Accounting, Islamic Azad University of Khorramabad, Iran \\ Correspondence: Masoud Taherinia, Department of management, Lorestan University, Khorramabad, Iran. \\ E-mail: esfehani.mohamad3@gmail.com
}

Received: June 2, 2016

Accepted: June 18, 2016

Online Published: July 11, 2016

doi:10.5539/mas.v10n12p48

URL: http://dx.doi.org/10.5539/mas.v10n12p48

\begin{abstract}
We studied the effect of corporate governance discipline on profit management of the accepted companies in the Stock Exchange of Tehran. The required data has been collected from a sample including120 companies accepted in the Stock Exchange of Tehran in the period of 2008 to2013. In this research, based on data types and statistical analysis methods, we have used combined data method and pooled regression analysis along with panel data. The results showed that there is a significant negative relation between characteristics of corporate governance discipline and profit management.
\end{abstract}

Keywords: corporate governance, profit management, TSE

\section{Introduction}

Accounting profit is one of the basic criteria of economic decision-making, but the variability of estimates and methods in accounting distorts validity and reliability of this profit. Besides these, there are some prerequisites such as conflict of interests between managers and owners of companies that increase the doubts about the reliability of profit.

Corporate governance that includes some mechanisms to direct the affairs of the company monitors activities in addition to run the company's affaires and thus minimizes the possibility of exerting personal demands of managers. Hence, it is expected that by implementing and strengthening the mechanisms of corporate governance, financial reporting quality and profit of company is increased (Salehi \& Ziaii, 2010).

Profit management is a form of profit manipulation with the possibility of reducing profit reliability. When profit management is controlled by supervisory systems, the accounting profit will be more reliable and contain more useful information. Corporate governance reduces managers' capacity to manage profit and has the ability to improve their liability of accounting profit and thus improves usefully informing feature of accounting profit (Aghaiiet al., 2009). So, considering the importance of the issue, the present research attempts to study the effect of corporate governance discipline on profit management of the accepted companies in Stock Exchange of Tehran.

\section{Theoretical Principles and Background of Research}

\subsection{Theoretical Principles of Research}

In 1994, Accounting International Federation defined corporate governance discipline as follows: "Governance discipline of commercial unit is a set of responsibilities and the methods used by the board of directors and bound managers aiming at clarifying a strategic way that guarantees achieving at objectives, controlling risks and responsibly using resources." 
Several different theoretical frameworks for describing and analyzing corporate governance have been proposed that each has addressed the topic using different words in a different way as a result of particular scientific fields looking at corporate governance discipline. For example, financial theory from financial and economic point of view, transaction cost theory from economic, legal and organizational point of view, and Stakeholders theory from social point of view address the corporate governance discipline.

Traditional economic theories recognize all economic agents' rational and increase business profits as primary target; On the contrary, transaction cost theory considers human behavior more realistically. In this model, managers and othereconomic agents apply limitedlogic. Simon (1957) defines limited logic as a behavior that is reasonable but managers doing this behavior limitedly.

\section{Transaction cost theory}

In this theory, company is not only a public economic unit (llp), but also an organization including people with different views and goals. Transaction costtheory is based on the fact that companies have become so big that replace market in resource allocation. In fact, companies are so big and complex that price fluctuations in market direct production and balance transaction market. Within company, some transactions are eliminated and manager coordinates production.

\section{Stakeholder Theory}

Stakeholder theory began to develop since 1970s. One of the first explanations of this theory in the field of management was presented by Friedman in 1984. He raised the company general theory and suggested accountability of company to a wider group of stakeholders. The base of Stakeholder theory is that companies have become very big and their effect on society is so deep that they should pay attention to more parts of society in addition to shareholders and be responsible for them and raise beneficiaries instead of shareholders. Beneficiaries include Shareholders, employees, vendors, customers, creditors, other companies and the public. The most extreme advocates of the stakeholder theory believe that the environment, animal species and the next generations should also be included in the group of beneficiaries (Hassas yeganeh, 2005).

The concept of profit management has been investigated in respect of various aspects and different related definitions have been provided. George et al. define profit management as an artificial gain of profit by management to achieve the expected level of profit for some specific decisions. In their opinion, actually the primary motivation of profit management is managing investors' perception of the commercial unit. Scott has defined profit management as informed attempts taken by the management on how to report a profit to achieve specific objectives according to the accounting principles.

\subsection{Research Background}

Table 1. Research Background Summary

\begin{tabular}{lll}
\hline \multicolumn{1}{c}{ Authors } & \multicolumn{1}{c}{ Title } & \multicolumn{1}{c}{ Result } \\
\hline $\begin{array}{l}\text { Setayesh and } \\
\text { Ebrahimi (2013) }\end{array}$ & $\begin{array}{l}\text { Effect of corporate } \\
\text { governance mechanisms on } \\
\text { profit informational content }\end{array}$ & $\begin{array}{l}\text { Profit informational content has a positive significant } \\
\text { relation with ownership focus and institutional ownership. }\end{array}$ \\
$\begin{array}{l}\text { Rahimian and } \\
\text { Relation between profit } \\
\text { quality and informational }\end{array}$ & $\begin{array}{l}\text { There is a significant relation between profit quality rate } \\
\text { and informational asymmetry, and reduction of profit }\end{array}$ \\
Mashayekhi and & $\begin{array}{l}\text { asymmetry } \\
\text { Relation of corporate }\end{array}$ & $\begin{array}{l}\text { Increased number of the boars' meeting and non-bound } \\
\text { managers' attendance in them increase accounting profit }\end{array}$ \\
Mohammad abadi & $\begin{array}{l}\text { governance mechanisms } \\
\text { and accounting profit }\end{array}$ & quality. \\
Izadinia and & $\begin{array}{l}\text { quality } \\
\text { Relation between profit }\end{array}$ & $\begin{array}{l}\text { There is a negative relation between profit quality and } \\
\text { percent of non-bound members of the board, and a positive }\end{array}$ \\
\hline
\end{tabular}




\begin{tabular}{|c|c|c|}
\hline & $\begin{array}{l}\text { corporate governance } \\
\text { mechanisms }\end{array}$ & $\begin{array}{l}\text { relation between profit quality and percent of institutional } \\
\text { investors. }\end{array}$ \\
\hline $\begin{array}{l}\text { Ho and Taylor } \\
\text { (2013) }\end{array}$ & $\begin{array}{l}\text { corporate governance and } \\
\text { different types of voluntary } \\
\text { disclosing }\end{array}$ & $\begin{array}{l}\text { Strong corporate governance structure affects on voluntary } \\
\text { disclosing information related to strategic and big } \\
\text { companies for manager and top manager, financial markets } \\
\text { and capital and social responsibility of companies. }\end{array}$ \\
\hline 'Ebad (2013) & $\begin{array}{l}\text { corporate governance and } \\
\text { investors perception of } \\
\text { profit quality }\end{array}$ & $\begin{array}{l}\text { Investors in companies having strong corporate governance } \\
\text { have a better perception of profit quality. }\end{array}$ \\
\hline $\begin{array}{l}\text { Siagian and } \\
\text { colleagues }\end{array}$ & $\begin{array}{l}\text { corporate governance, } \\
\text { Reporting quality and } \\
\text { company value }\end{array}$ & $\begin{array}{l}\text { Companies having powerful corporate governance are more } \\
\text { valuable. Also, reporting quality has a reverse relation with } \\
\text { company validity. }\end{array}$ \\
\hline $\begin{array}{l}\text { Luntiys and } \\
\text { DimitrovPulus } \\
\text { (2012) }\end{array}$ & $\begin{array}{l}\text { Role of corporate } \\
\text { governance in profit } \\
\text { management }\end{array}$ & $\begin{array}{l}\text { Banks have less profit management by efficient corporate } \\
\text { governance. }\end{array}$ \\
\hline
\end{tabular}

\section{Research Method}

In respect of classifying based on objective, this study is an applied research and based on the nature and research methods, belongs to correlation researches. In this study, according to the type of data and methods of statistical analysis, the combined data method and pooled regression analysis along with panel data will be used. To have significant hypotheses, we will use T-student test. Statistic F will be used for regression equation test. Tests such as Chow test, Hausman and LM tests are used to determine the used model for the combined data. To identify self-correlation and or being self-correlated of disturbing sentences, Durbin- Watson test and Tobin Q-test will be used

\subsection{Research Hypotheses}

The main hypothesis is:

There is a significant relation between the structure of corporate governance discipline and profit management. The sub hypotheses are:

1. There is a significant relation between the size of the board and profit management.

2. There is a significant relation between the percent of board members' not-being bound and profit management.

3. There is a significant relation between quality of financial information and profit management.

\subsection{Statistical Sample and Population}

The research population includes all companies accepted in Stock Exchange of Tehran. After applying the limitations, 120 companies have had all requirements of presence in the sample.

\subsection{Methods and Data Collecting Tools}

In this research, the necessary data are collected from primary and secondary resources as books, prominent related articles, prominent related studies, the website of Stock Exchange of Tehran, the website of Islamic studies, and also software "Tadbir pardaz", Internet sites such as SSRN, Springer, Science Direct, SID etc.

\subsection{Research Patterns}

The research model is a general case of a multi variety regression model with combined data as follows:

$\mathrm{U}=\alpha+\mathrm{b}_{1} \mathrm{X}+\mathrm{b}_{2} \mathrm{Y}+\mathrm{b}_{3} \mathrm{Z}+\mathrm{b}_{4} \mathrm{E}+\mathrm{b}_{5} \mathrm{~S}+\varepsilon 0$

$\mathrm{B}_{1}, \mathrm{~b}_{2} \ldots, \mathrm{b}_{\mathrm{K}}$ : coefficients of the independent variables

a:constant

U: Profit managementas the dependent variable

$\mathrm{X}$ : The size of the board of directors (independent variable)

Y: not-being bound of the board of directors (independent variable)

Z: Quality financial information (independent variable) 
E: Leverage (auxiliary variable)

S: Company size (auxiliary variable)

In this study, the modified Jones model is used to measure profit management:

In the modified Jones model, discretionary accruals are used as an indicator for profit management. Discretionary accruals: This section of accruals is usually the result of reducing non-discretionary accruals from the total accruals.

A) The starting point of the above model is finding the accruals sum via the following equation:

$$
\mathbf{T A}_{\mathrm{t}}=\frac{\Delta \mathrm{CA}_{\mathrm{t}}-\Delta \mathrm{CL}_{\mathrm{t}}-\Delta \operatorname{cash}_{\mathrm{t}}+\Delta \mathbf{S T D}_{\mathrm{t}}-\mathbf{D e p}_{\mathrm{t}}}{\mathbf{A}_{\mathrm{t}-1}}
$$

$\mathrm{TA}_{\mathrm{t}}=$ Total accruals of year $\mathrm{t}$.

$\Delta \mathrm{CA}_{\mathrm{t}}=$ Change of current assets in the year

$\Delta \mathrm{CL}_{\mathrm{t}}=$ Change of current debts in year $\mathrm{t}$

$\Delta \operatorname{cash}_{\mathrm{t}}=$ Change of cash and cash equivalent in year $\mathrm{t}$

$\Delta \mathrm{STD}_{\mathrm{t}}=$ Change of current share of payable facilities in year $\mathrm{t}$

Dep $_{\mathrm{t}}=$ depreciation expense in year $\mathrm{t}$

$A_{t-1}=$ Total assets of year $t-1$

B) The next step is calculating the non-discretionary accruals using the following formula:

$$
\mathrm{NDA}_{\mathrm{t}}=\alpha_{1}\left(\frac{1}{\mathrm{~A}_{\mathrm{t}-1}}\right)+\alpha_{2}\left[\frac{\Delta \mathrm{REV}_{\mathrm{t}}-\Delta \mathrm{REC}_{\mathrm{t}}}{\mathrm{A}_{\mathrm{t}-1}}\right]+\alpha_{3}\left(\frac{\mathrm{PPE}_{\mathrm{t}}}{\mathrm{A}_{\mathrm{t}-1}}\right)
$$

$\mathrm{NDA}_{\mathrm{t}}=$ non-discretionary accruals in year $\mathrm{t}$

$A_{t-1}=$ total assets of year $t-1$

$\triangle \mathrm{REV}_{\mathrm{t}}=$ change of net of income of company in year $\mathrm{t}$ relative to year $\mathrm{t}-1$

$\Delta \mathrm{REC}_{\mathrm{t}}=$ change of net of accounts and commercial receivable documents in year $\mathrm{t}$ relative to year $\mathrm{t}-1$

$\mathrm{PPE}_{\mathrm{t}}=$. of estate, machinery and equipments in year $\mathrm{t}$

To estimate $\alpha 1, \alpha 2$ and $\alpha 3$, the following model is used:

$$
\mathrm{TA}_{\mathrm{t}}=\alpha_{1}\left(\frac{1}{\mathrm{~A}_{\mathrm{t}-1}}\right)+\alpha_{2}\left[\frac{\Delta \mathrm{REV}_{\mathrm{t}}-\Delta \mathrm{REC}_{\mathrm{t}}}{\mathrm{A}_{\mathrm{t}-1}}\right]+\alpha_{3}\left(\frac{\mathrm{PPE}_{\mathrm{t}}}{\mathrm{A}_{\mathrm{t}-1}}\right)+\varepsilon_{\mathrm{t}}
$$

Coefficients $\alpha_{1}, \alpha_{2}$ and $\alpha_{3}$ are specific parameters of company that are estimated; TA is sum of accruals . Finally, discretionary accruals are resulted by reducing non-discretionary accruals from the sum of accruals (Bozorgmehr and Shayestehmand, 2011).

Model 2:

$$
\mathrm{DAt}=\mathrm{TA}_{\mathrm{t}}-\mathrm{NDA}_{\mathrm{t}}
$$

\subsection{Research Variables}

\begin{tabular}{llll}
\hline Hypotheses & Independent variable & relation & Dependent variable \\
\hline main & Corporate governance discipline & $>$ & Profit management \\
$\mathrm{Sub}_{1}$ & Board size & $>$ & Profit management \\
$\mathrm{Sub}_{2}$ & Percent of not-being bound of the board's members & $>$ & Profit management \\
$\mathrm{Sub}_{3}$ & Quality of financial information & $>$ & Profit management \\
\hline
\end{tabular}

\section{Analysis}

\subsection{Descriptive statistics}

\subsubsection{Research descriptive statistics}


Table 1. Results of research descriptive statistic

\begin{tabular}{lllllll}
\hline & Size & Qa & Bind & Bsiz & Da & Leve \\
\hline Mean & 5.81 & 0.27 & 0.44 & 5.09 & 0.11 & 0.62 \\
Median & 5.76 & 0.26 & 0.6 & 5 & 0.06 & 0.65 \\
Maximum & 8.6 & 0.82 & 0.85 & 9 & 0.28 & 0.79 \\
Minimum & 2.89 & 0.00 & 0.00 & 3 & 0.01 & 0.00 \\
Standard deviation & 0.63 & 0.19 & 0.32 & 0.50 & 0.08 & 0.14 \\
Skewness & 0.54 & 0.25 & -0.45 & 0.07 & 0.57 & -1.46 \\
Observation & 720 & & & & & \\
\hline
\end{tabular}

Reference: Researcher's calculations

\subsubsection{Correlation Coefficients Test}

Table 2. Results of Pierson correlation coefficients among research variables

\begin{tabular}{lllll}
\hline Covariance Analysis: Spearman rank-order & & & \\
Date: 04/23/15 Time: 22:23 & & & \\
Sample: 2008- 2013 \\
Included observations: 720 \\
Correlation
\end{tabular}

Reference: Researcher's calculations

\subsubsection{Research reliability test}

\subsubsection{Unit root test}

Reliability of research variables should be examined before analyzing and testing hypotheses. The reliability of the research variables means that the mean and variance of variables has been constant during different years. As a result using these variables in the model doesn't cause False-regression. Unit root test has been conducted using test methods of Levin, Lin and Chu (2002), the generalized Dickey Fuller, Fisher's unit root test and unit root test of Fisher, Philips, Peru (2001). Results of variable reliability test show that p.v of all variables is less than 5\% and the research variables are reliable; therefore, the null hypothesisof having unit rootis rejected. 
Table 3. Unit root test for variables

\begin{tabular}{|c|c|c|c|c|c|c|}
\hline variables & $\begin{array}{l}\text { Levin, Lin } \\
\text { Choe }\end{array}$ & and & $\begin{array}{l}\text { Generalized Fisher, } \\
\text { Fuller }\end{array}$ & Dickey & $\begin{array}{l}\text { Fisher, } \\
\text { philips/Peru }\end{array}$ & \\
\hline & Statistic & p.v & statistic & p.v & Statistic & p.v \\
\hline DA & $8,22-$ & 0,000 & 145,7 & 0,00 & 277,01 & 0,04 \\
\hline bsize & $2,90-$ & 0,000 & 211,7 & 0,00 & 139,4 & 0,00 \\
\hline bind & $10,66-$ & 0,000 & 194,4 & 0,000 & 107,08 & 0,000 \\
\hline qa & $15,6-$ & 0,000 & 212,4 & 0,000 & 268,3 & 0,000 \\
\hline
\end{tabular}

Reference: Researcher's calculations

\subsubsection{Steps of Estimating Model by Combined Data}

To test the hypotheses, the combined data method is used. To select the appropriate method for estimating the models in different time periods of combined data, bound $\mathrm{F}$ test (Chow) was used. If statistic $\mathrm{F}$ is larger than the critical value, constant effect model is accepted and otherwise, and if the research data is appropriate, the method of pooled or integrated data is used to test the hypotheses. As shown in table (4-4), the results of Chaw test has strongly confirmed H0, i.e. similarity of (intercept) in all periods, for the research model (error level is more than 5 percent). So, "pooled data estimating method" is more appropriate to estimate test models of research hypotheses. According to this method, all data are combined with each other and estimated by ordinary least squares regression (OLS).

Table 4. Results of Chaw test (bound F) in studying research hypotheses

\begin{tabular}{lllllll}
\hline Chaw test & Statistic F & $\begin{array}{l}\text { Critical } \\
\text { Quantity }\end{array}$ & p-value & & Results of Chaw test & Test type \\
\hline $\begin{array}{l}\text { H0: } \quad \text { The } \\
\text { 1,11 of (intercept) }\end{array}$ & Sam & eness & 5,70 & 0,23 & $\begin{array}{l}\text { H0 } \\
\text { notrejected }\end{array}$ & is \\
\hline
\end{tabular}

Reference: Researcher's calculations

\subsection{Inferential Statistics}

\subsubsection{Analyzing Hypotheses Using Combined Data}

In practice, there are two criteria for acceptance or rejection of research hypotheses:

1. The rate of test significance ( $\mathrm{p}$ - value or sig) is less than 0.05 .

2. The absolute value of statistic T-student at confidence level $95 \%$ is greater than 2 .

In each case, the resulted value of test statistic rejects H0 (null hypothesis) and thus confirmed H1 (hypothesis 1).

We use statistic T-student to test H0. Accordingly if the resulted significance coefficient is less than $0 / 05$, H0 is rejected and its opposite hypothesis is accepted. Accepting the opposite hypothesis means that there is a significant linear relationship between independent variables and the dependent variable tested in the model designed for the research hypotheses.

Research Statistical hypotheses are formulated as follows:

$\mathrm{H} 0$ : There is no correlation between the independent variables and profit management.

H1: There is correlation between the independent variables and profit management.

Therefore if sig (P-Value) $<0 / 05$, then $\mathrm{H} 0$ is rejected and $\mathrm{H} 1$ is accepted. According to the multivariate Model, if the coefficient of each independent variable (i.e. $\beta_{i} \mathrm{~s}$ ) is positive, the mentioned independent variables have a direct relation with dependent variable (i.e. profit management), and if the coefficient is negative, the relation will be reversed. To examine the significance of the model generally and the relation of each independent variable with the dependent variable, statistics $\mathrm{F}$ and $\mathrm{t}$ are used respectively. Also, Durbin- Watson test is used to examine self-correlation among residuals of regression error. If statistic of this test is close to the number 2 , there's a lack of correlation among residuals. 


\subsubsection{Result of Research Model Test}

Table 5. Results of research model test at the level of combined data

\begin{tabular}{lll}
\hline Description coefficientp-value T-student & $\begin{array}{l}\mathrm{F} \text { - statistic } \\
\text { p.v }\end{array}$ & Durbin-Watson \\
\hline$\ldots \ldots .0,306,830,00$ & 7,82 & 2,07 \\
Bsize $0,01-2,67-0,00$ & 0,000 & \\
bind $0,042,44-0,00$ & & \\
qa $0,06-3,99-0,00$ & & \\
Size $0,03,060,00$ & & \\
Level0,023,26 0,00 & & \\
Determination coefficient 0,59 & & \\
Modified determination coefficient (R2) 0,45 & \\
\hline
\end{tabular}

As indicated in the table (5), statistic $\mathrm{F}$ with a confidence level of $99 \%$ is significant. Therefore, the research model has been significant totally and the control and independent variablesare able to explainthe dependent variable. In addition, the modified determination coefficient resulted from testing the model has been 0.45 . This figure shows that approximately $0.45 \%$ of the changes of the dependent variable (i.e. profit management) of accruals are caused by the control and independent variables in the model, and $0 / 55 \%$ by other factors. Also, considering statistic values of Durbin- Watson test proves that there isn't self-correlation among disturbing parts of the model, because these values are from $1 / 5$ to $2 / 5$.

\subsubsection{The First Hypothesis}

"There is a significant relationbetween the size ofthe board of directorsand profit management."

In this hypothesis, the profit management is dependent variable and the size of the board is independent variable. According to the results of figure (2), the correlation between profit management and the board size has been $0.07-$.The correlation coefficient is the rate of variability of the dependent variable which can be explained by the regression.

According to the results of table (6), statistic t related to the independent variable of the board size (BSIZE) and its significance level (p-value) are the 2.67- and 0.00, respectively. Given that the considered error level for this research is $0 / 05$, the board size variable has a significant effect on profit management and the first hypothesis of the research is confirmed at level $95 \%$. The variable coefficient (BSIZE) is negative, i.e. when the board size increases, profit management decreases. This result means that according to the supervisory role of the board members, the more the number of these people, the less exerting profit management due to conflict of stakeholders and members' interests.

Table 6. Results of coefficients significance test in the first hypothesis

\begin{tabular}{ll}
\hline Time period & $2008-2013$ \\
\hline Statistic t & $2,67-$ \\
(p-value) & 0,00 \\
Coefficient & $0,01-$ \\
Number of observations & 720 \\
Result of hypothesis & confirmed \\
Relation type & reversed \\
\hline
\end{tabular}

Reference: Researcher's calculations

\subsubsection{The Second Hypothesis}

"There is a significant relation between not-being bound of the board's members and profit management."

In this hypothesis, the profit management is dependent variable and the not-being bound of the board members is independent variable. According to the results of figure number (2), the correlation between profit management 
and not-being bound of the board's membershas been $0.03-$.

According to the results of table (7), statistictrelated to theindependent variable of not-being bound of theboard's members(bind)and its significance level(p-value)has been2.44-and0.00, respectively. Given that the considered error level for this research is $05 / 0$, the variable of not-being bound of the board's members has a significant effect on profit management and the second hypotheses is confirmed at the confidence level $95 \%$. The variable coefficient (bind) is negative. As a result, the relation between not-being bound of the board's members and profit management is reverse and negative. In other words, by increasing the number of non-bound members of the board, profit management decreases.

Table 7. Results of coefficients significance test in the second hypothesis

\begin{tabular}{ll}
\hline Time period & $2008-2013$ \\
\cline { 2 - 3 } Statistic $\mathrm{t}$ & $2,44-$ \\
$(p$-value $)$ & 0,00 \\
Coefficient & $0,04-$ \\
Number of observations & 720 \\
Result of hypothesis & confirmed \\
Relation type & reversed \\
\hline
\end{tabular}

Reference: Researcher's calculations

This result means that the role of non-bound directors in Iran is according to the agency theory and the ability of this regulatory tool to reduce profit management is strong. According to the agency theory, the presence of independent non-bound directors in the board of company and their regulatory function as independent people help reduce the available conflicts of interests between shareholders and managers.

\subsubsection{The third hypothesis}

"There is a significant relationbetweenthe quality of financialinformationand profit management."

In this hypothesis, the profit management is dependent variable, and the quality of financial information is independent variable. According to the results of figure (2), the correlation between profit management and the quality of financial information has been 0.19-. According to the results of table (8), statistic $t$ related to the independent variable quality of financial information (qa) and its significance level (p-value) has been 3.99- and 0.00 , respectively. Given that the error level considered for this study is $0 / 05$, the variable of financial information quality has a significant effect on profit management and the third hypotheses of the research is also confirmed at the confidence level 95\%. Variable coefficient (QA) is negative. As a result, the relationship between the quality of financial information and profit management is reverse and negative. In other words, by increasing the quality of financial information, profit management decreases.

Table 8. Results of coefficients significance test in the third hypothesis

\begin{tabular}{ll} 
Time period & $2008-2013$ \\
\hline Statistic t & $3,99-$ \\
(p-value) & 0,00 \\
Coefficient & $0,06-$ \\
Number of observations & 720 \\
Result of hypothesis & confirmed \\
Relation type & reversed \\
\hline
\end{tabular}

Reference: Researcher's calculations

\section{Conclusion}

In this research, we investigated the relation between the structure of corporate governance discipline and profit management of accruals. Based on the combined data, results showed that there is a significant negative relationship between the structure of corporate governance discipline (include size of the board, not-being bound of the board, the quality of financial information profit) and management and as a result, the main hypothesis was confirmed at the confidence level $95 \%$. The results of this hypothesis are consistent with the 
results of researches of Mustafa Suleiman and Ahmed Rajab (2013) and Zahri and Shabwa (2013).

\section{References}

AbuiiMehrizi, A. (2011). The study of relationship among corporate disclosure quality, profit quality and capital (cost) of the accepted companies in Stock Exchange of Tehran, M.A. thesis, Islamic azad university of yazd.

ASX. Corporate governance council (2007). Corporate governance principles and recommendations with 2010 Amendments, ISBN 1875262423.

Baradarane, H. R., Taghizadeh, H., Rezaii, A. S. (2011). Studying the effect of combining stakeholders on informational content of accounting profit of the accepted companies in Stock Exchange of Tehran. Journal Of Financial Accounting Researches, 3(8), 107 - 124.

Chang, J., Sun, H. (2010). Does the disclosure of corporate governance structures affect firms earnings quality? Review of accounting and finance, 9(3), $212-243$.

Dechow, P., \& Dichev, I. (2002). The quality of accruals and earnings : the role of accrual estimation errors. The Accounting Review, 77, 35-59.

Dehghan, F. W. (2011). The effect of corporate governance structure on quality of disclosing information of the accepted companies in Stock Exchange of Tehran, M.A. thesis. Yazd Azad University.

Demirbas , D., Yukhanae, A. (2011). Independence of board of directors, employee relation and harmonization of corporate governance. Employee Relations, 33, 444-471. Emerald group publishing limited 0142-5455.

EbrahimiKordlou, A., \& Arabi, M. (2010). The focus of ownership and profit quality in the accepted companies in Stock Exchange of Tehran. Journal of Financial Accounting Researches, 2(2), 95 - 110.

Firth, M., Fung, P., \& Oliver, M. (2007). Ownership , two -tier board structure and the in formativeness of earnings - evidence from china. Journal of Accounting and Public Policy, 26, 463-496.

Izadinia, N., \& Rasaiian, A. (1390). Mechanism of corporate governance discipline and profit quality. Experimental Researches Quarterly of Financial Accounting, 1(1).

Mashayekhi, B., \& Mohammadabani, M. (2011). Relation of corporate governance mechanism with profit quality. Journal of Financial Accounting Researches, 3(2), 17 - 32.

Mehrani, K., \& Safarzadeh, M. W. (2011). Explaining relationship between corporate governance and profit quality by local approach. Journal of Accounting Knowledge, 2(7),69-98.

Mehrani, S., Karami, Q. H., Moradi, M., \& Eskandar, H. (2010). Studying relation between institutional investors and financial reporting quality. Journal of Accounting Advancements of Shiraz University, 2(1), $249-227$.

Nikoomaram, H., Mohammadzadehsaleteh, H. (2010). Providing a pattern to explain the relation between corporate governance and profit quality. Journal of Management Accounting, 3(4).

Setayesh, M., \& Ebrahimi, F. B. (2012). Studying the effect of corporate governance mechanisms on profit informational content of the accepted companies in Stock Exchange of Tehran. Journal of Accounting knowledge, 3(8), 31-45.

\section{Copyrights}

Copyright for this article is retained by the author(s), with first publication rights granted to the journal.

This is an open-access article distributed under the terms and conditions of the Creative Commons Attribution license (http://creativecommons.org/licenses/by/3.0/). 